\title{
DIAMETRIC GROWTH AND PROPERTIES OF Copaifera langsdorffii DESF. BY SECOND CUTTING CYCLE
}

\author{
Jair Figueiredo do Carmo ${ }^{1 *}$, João Vicente de Figueiredo Latorraca ${ }^{2}$, Glaycianne Christine Vieira dos Santos ${ }^{3}$, \\ Fábio Henrique Della Justina do Carmo ${ }^{1}$, Dirceu Lúcio Carneiro de Miranda ${ }^{1}$, José Luis Penetra Cerveira \\ Lousada $^{4}$ \\ ${ }^{1}$ Federal University of Mato Grosso, Institute of Agriculture and Environmental Sciences, Sinop, Mato Grosso, Brazil - \\ carmo.jair@gmail.com*; fabiocarmo.ef@hotmail.com; mirandaufmt@hotmail.com \\ ${ }^{2}$ Federal Rural University of Rio de Janeiro, Institute of Forestry, Department of Forest Products, Seropédica, Rio de Janeiro, Brazil - \\ latorraca@hotmail.com \\ ${ }^{3}$ Federal Rural University of Rio de Janeiro, Institute of Forestry, Graduate Program in Environmental and Forest Sciences, Seropédica, Rio \\ de Janeiro, Brazil - annechristine.santos@hotmail.com \\ ${ }^{4}$ University of Trás-os-Montes and Alto Douro, Department of Forest Sciences and Landscaping, Vila Real, Portugal - jlousada@utad.pt
}

Received for publication: 15/01/2018 - Accepted for publication: 27/03/2018

\begin{abstract}
The aim of this study was to analyze forest management effects in the diametric growth and wood anatomical, chemical and physical properties of Copaifera langsdorffii trees, in an Ombrophilous Open Forest (state of Mato Grosso, Brazil). The forest management effects were determined through a comparative study between the wood properties of 10 years before and 10 years after the first logging, in 1987. Multivariate associations among the anatomical characteristics, macro and micronutrient, wood density, and current annual increment (ICA) were evaluated to every growth period through the two steps cluster analysis. The results indicated that the following characteristics were relevant to distinct the periods studied: ICA, vessel frequency, and wood density. C. langsdorffii respond to stimuli caused by forest management, adapting to the increase of resources availability, due to the opening gaps, and showing growth increase with reduction of wood density, which may indicate variations on the wood properties.

Keywords: Wood quality, forest management, tropical wood.
\end{abstract}

\section{Resumo}

Crescimento diamétrico e propriedades do lenho de Copaifera langsdorffi desf. De segundo ciclo de corte. O objetivo do presente estudo foi analisar os possíveis efeitos do manejo florestal no crescimento diamétrico e nas propriedades anatômicas, químicas e físicas da madeira de Copaifera langsdorffii, em Floresta Ombrófila Aberta (Mato Grosso, Brasil). O efeito do manejo florestal foi determinado por meio de um estudo comparativo entre as características tecnológicas do lenho correspondente a dez anos antes e dez anos após a primeira exploração, ocorrida em 1987. Foram avaliados: associações multivariadas entre as características anatômicas, macro e micronutrientes, densidade aparente e incremento corrente anual (ICA), em cada período analisado, por meio de análise de cluster em duas etapas. Os resultados indicaram que as seguintes características foram relevantes para a distinção dos períodos estudados: ICA, frequência de vasos e densidade da madeira. Diante dos resultados obtidos, pode-se concluir que a espécie arbórea $C$. langsdorffii responde aos estímulos provocados pelo manejo florestal, adaptando-se ao aumento da disponibilidade de recursos decorrentes da abertura de clareiras e apresentando ganhos de incremento com redução na densidade, o que pode indicar adaptações das propriedades da madeira.

Palavras-chave: Qualidade da madeira, exploração florestal, madeira tropical.

\section{INTRODUCTION}

The concept of sustainable forest management refers to the balance between the social, economic and environmental impacts associated with the forest resources in order to ensure the availability of the same for future generations (HICKEY, 2008). Arose from the need to discipline the unbridled forest exploitation and for the care of the particularities of the Amazon Forest (CASTELO, 2015).

It is known that forest management techniques may impact the functional structure of the arboreous and herbaceous species in different forest types, modifying the characteristics of leaves, stems, flowers and fruits (KUSUMOTO et al., 2015). Therefore, it is of utmost importance to understand how management practices impact the plant species, especially the arboreous ones. 
Copaiba (Copaifera langsdorffii Desf.) is a native tree species, widely distributed in the Brazilian territory and of great economic importance, especially in the Amazon region, due to the good quality of its wood and the oilresin production. The economic importance of the oil produced and extracted from species of the genus Copaifera in general has stimulated the development of studies about the species management, aiming at gains in product quality and yield (MEDEIROS et al., 2018). However, the effect of forest management in the wood of these trees, especially in conditions of natural forest, is still discussed in the literature in a very incipient way.

The various practices of forest management, such as the removal of pre-selected trees, are directed to the quality of plantations maintenance, which reduces competition among the remaining trees and provides growth in diameter due to the greater resources availability (LONGHI $e$ al., 2018). Because of the thinning intensity, the increase in diameter may promote changes in consumption and efficiency of water use by trees, which occur in function of the water availability in the environment and the capacity of the arboreous species adaptation (PARK et al., 2018).

The trees radial growth, provided by the activities of forest management, can impact the wood properties by means of changes in wood anatomy. However, these possible modifications are still not fully understood, which justifies the realization of studies designed to determine the impact of silvicultural interventions, promoted by the forest management, about the wood quality. Considering the above, the objective of this study was to analyze the forest management effects on diameter growth and anatomical, chemical and physical properties of wood from Copaifera langsdorffii of second cutting cycle in Open Ombrophilous Forest.

\section{MATERIAL AND METHODS}

\section{Characterization of the study area}

The material collection is located to the north of the state of Mato Grosso, south of the Brazilian Amazon, characterized as humid tropical forest of terra firme and described as Evergreen Seasonal Forest (IBGE, 2012). The first forest exploitation in the area occurred in 1987. After 25 years (2013), there was a second operation with an intensity of approximately $25 \mathrm{~m}^{3} \cdot \mathrm{ha}^{-1}$ (around 5 trees.ha $^{-1}$ ). The forest management plan in the area provides a cutting cycle (polycyclic) established for 25 and 35 years, following the environmental legislation for the forest management activity in the Legal Amazon.

\section{Sampling and determination of the current annual increment (ICA)}

All eight remaining trees of the first phase of exploitation were sampled which presented a diameter greater than $50 \mathrm{~cm}$, complying with the criteria listed for forest management. The diameters of these remaining trees varied from 51 to $98 \mathrm{~cm}$.

From the disks obtained from the base of the trees radial sections were removed (toward pith-bark), from which the corresponding regions were delimited. The specimens of $C$. langsdorffii were catalogued in the Herbário Centro-Norte-Mato-Grossense (CNMT) of the Federal University of Mato Grosso (UFMT), under the registration 7603 (botanical material), and in the wood collection of the Department of Forest Products of the Federal Rural University of Rio de Janeiro (UFRRJ), under the registration numbers 7593, 7594, 7595 and 7596.

The impact of the first forestry exploitation was assessed by means of a comparative study among the technological properties (anatomical, physical and chemical properties) of the wood corresponding to ten years before (1978 to 1987) and ten years after (1988 to 1997) the first forest exploitation. For the dating of growth rings corresponding to these two periods, a preliminary study of dendrochronology was developed, sampling other 12 trees by means of non-destructive collection of baguettes and using an increment drilling.

The current annual increment (ICA) was determined from the definition and measurement of the width of growth rings dated by dendrochronology study performed with MSR2 sections of 20 sampled trees.

\section{Anatomical analyzes}

The quantitative anatomical analyzes were performed from histological and dissociation of woody tissues corresponding to each period of study. For the characterization of the anatomical radial profile, the following variables were measured every $1 \mathrm{~cm}$ : frequency (vessels. $\mathrm{mm}^{-2}$ ); tangential diameter and length of the vessels elements $(\mu \mathrm{m})$; height and width of the rays $(\mu \mathrm{m})$; length, lumen diameter and wall thickness of the fibers $(\mu \mathrm{m})$.

The cuts were obtained in the slide microtome (Leitz 1208), with a thickness of between 12 and $18 \mu \mathrm{m}$ in transverse, tangential and radial longitudinal plans, clarified in $60 \%$ sodium hypochlorite and stained with hydroalcoholic safranin of $1 \%$ (Johansen, 1940). The dissociation of anatomical elements was performed from fragments of wood, sectioned in the fibers direction, kept in a solution of hydrogen peroxide and acetic acid (1:1) to $70^{\circ} \mathrm{C}$ during $8 \mathrm{~h}$. All measurements were performed according to the standards established by the International Association of Wood Anatomy Committee (IAWA, 1989) and analyzed by means of the software Leica DM. 


\section{Densitometric measurements}

The densitometry analyzes were conducted in the Laboratory of Forest Engineering of the University of Trás-os-Montes and Alto Douro (UTAD), Vila Real, Portugal. The radial profiles of apparent density were obtained in radial sections of $3 \mathrm{~mm}$ of thickness, removing the disks of the basis of eight trees collected. Afterwards, they were wrapped in air-conditioned environment until the moisture stabilization (12\% of moisture). The densitometric radial profiles were constructed from individual measurements of apparent density using the micro densitometry technique of X-rays (Hewlett Packard, Faxitron 43805N; 1.20 m away from the source of X-ray film) and calibrated with wedge of cellulose acetate. The samples were radiographed ( $5 \mathrm{~min}$ of exposure, $16 \mathrm{Kv}$ accelerating voltage in tube, $3 \mathrm{~mA}$ due to the cathode heating) and digitized in appliance Microdensitometer 3CS.

\section{Macro and micronutrients in the cell wall}

The total quantification of macro and micronutrients present in the wood was performed by means of optical emission spectrometry by inductively coupled plasma (ICP-OES). The portions for each period analyzed were transformed into chips in the fraction of $0.200 \mathrm{~mm}$ and digested in $\mathrm{HNO}_{3} 20 \%$ v/v and $\mathrm{H}_{2} \mathrm{O}_{2} 30 \% \mathrm{~m} / \mathrm{m}$ in a vial of $\mathrm{TFM}^{\circledR}$.

\section{Statistical analyzes}

Multivariate associations were assessed among the anatomical characteristics, macro and micronutrients, apparent density and increased annual current, in each analyzed period, by means of two step cluster analysis. The grouping was performed according to the Bayesian Information Criterion (BIC), using as distance measure the log- likelihood. The significance of the variables within each cluster was determined by means of the Bonferroni test T-Test, at the level of $95 \%$ confidence intervals. To do this, IBM ${ }^{\circledR}$ statistical package SPSS ${ }^{\circledR} 15.0$ was used.

\section{RESULTS}

The two step cluster analysis distinguished both periods analyzed on the basis of apparent density, frequency of vessels and annual current increase, demonstrating the importance of these variables in the groups' segmentation (Table 1). The other evaluated anatomical characteristics showed no significant differences (at the level of $95 \%$ confidence interval). In general, the pre-exploratory period was characterized by: trees with higher apparent density and lower ICA; reduction in the number of vessels. $\mathrm{mm}^{-2}$ and length of vessel elements and an increase in the tangential diameter of these elements; larger and wider rays; and fibers whose characters (wall thickness, length and total diameter) were similar to the post-exploratory period.

Table 1. Two step cluster analysis for the anatomical characteristics, apparent density and current annual increment of Copaifera langsdorffii, between before (1978-1987) and after (1988-1997) the first logging.

Tabela 1. Análise de cluster em duas etapas para as características anatômicas, densidade aparente e incremento corrente anual de Copaifera langsdorffii, entre os períodos pré (1978-1987) e pós (1988-1997) exploratórios.

\begin{tabular}{|c|c|c|c|}
\hline \multirow[b]{2}{*}{ Variable } & \multicolumn{3}{|c|}{ Cluster } \\
\hline & $\begin{array}{c}1 \\
(1977-1987)\end{array}$ & $\begin{array}{c}2 \\
(1988-1997)\end{array}$ & Importance in Segmentation \\
\hline Apparent density $\left(\mathrm{kg} \cdot \mathrm{m}^{-3}\right)$ & 740 & 690 & $*$ \\
\hline Current annual increment (mm) & 202.55 & 270.10 & $*$ \\
\hline Vessels (frequency.mm-2) & 5.38 & 6.46 & $*$ \\
\hline Rays height $(\mu \mathrm{m})$ & 450.44 & 392.77 & NI \\
\hline Tangential diameter of vessels $(\mu \mathrm{m})$ & 122.28 & 115.75 & NI \\
\hline Rays width $(\mu \mathrm{m})$ & 44.28 & 40.17 & NI \\
\hline Fibers wall thickness $(\mu \mathrm{m})$ & 4.71 & 4.76 & NI \\
\hline Total diameter of fibers $(\mu \mathrm{m})$ & 21.75 & 21.96 & NI \\
\hline Vessel element length $(\mu \mathrm{m})$ & 294.70 & 297.47 & NI \\
\hline Fibers length $(\mu \mathrm{m})$ & 1376.50 & 1376.61 & $\mathrm{NI}$ \\
\hline
\end{tabular}

*: Important; NI: No importance. 


\section{Effect of management in the trees growth}

The diametric increments were evaluated in 10 years pre and post the forestry exploitation in 1987. The values found show a gain of pronounced diameter increment. Out of the 12 trees considered, only two (11 and 12) showed a distinct behavior, that is, a slight reduction in the increment after the intervention period (Figure 1). The global average increase was $6.85 \mathrm{~mm}$, with an increase of $19.64 \%$ between before and after first logging.
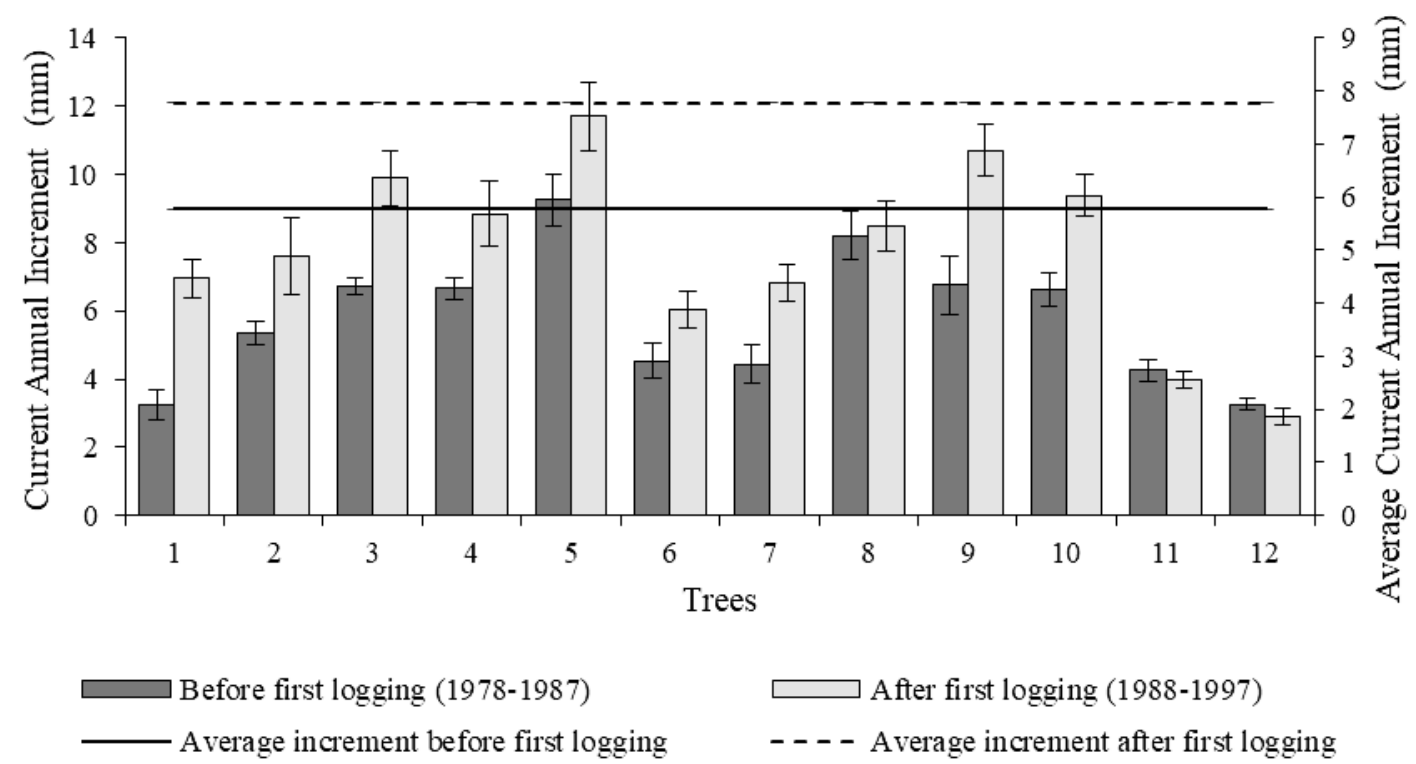

Figure 1. Current annual increment (ICA) of Copaifera langsdorffii before (1978-1987) and after (1988 - 1997) first logging.

Figura 1. Incremento corrente anual (ICA) de Copaifera langsdorffii nos períodos pré (1978-1987) e pós (19881997) exploração.

\section{Anatomical characteristics and apparent density}

In general, the anatomical characteristics related to tangential diameter and length of the vessels elements, wall thickness of the fibers, height and width of the rays and apparent density showed a reduction after the intervention of 1987. In contrast, the frequency of vessels, total thickness and length of the fibers showed a slight increase (Table 2). However, only the apparent density and frequency of vessels were relevant to the distinction between the periods analyzed, as shown in Table 1. After the intervention of 1987, there was a reduction in apparent density in the trees of $C$. langsdorffii (Table 2). This fact was expected, mainly due to the increase in the frequency of vessels. However, this reduction was not enough to change the class of wood density, which remained high.

Table 2. Descriptive statistics of the anatomical variables and wood density for the periods before (1978-1987) and after (1988-1997) the first Copaifera langsdorffii logging.

Tabela 2. Estatística descritiva das variáveis anatômicas e densidade aparente para os períodos pré (1978-1987) e pós (1988-1997) exploratórios de Copaifera langsdorffii.

\begin{tabular}{|c|c|c|c|c|c|c|c|c|}
\hline \multirow{3}{*}{ Variable } & \multicolumn{8}{|c|}{ Period } \\
\hline & \multicolumn{4}{|c|}{ Before first logging } & \multicolumn{4}{|c|}{ After first logging } \\
\hline & Min & Average & Max. & $\mathrm{CV}(\%)$ & Min & Average & Max. & $\mathrm{CV}(\%)$ \\
\hline \multicolumn{9}{|l|}{ Vessels } \\
\hline Frequency (vessels.mm²) & 2 & 5 & 9 & 29.64 & 2 & 6 & 9 & 25.25 \\
\hline Tangential diameter $(\mu \mathrm{m})$ & 54.71 & 120.75 & 190.19 & 20.17 & 55.15 & 117.24 & 194.37 & 23.34 \\
\hline Length $(\mu \mathrm{m})$ & 104.52 & 299.24 & 505.76 & 29.68 & 93.44 & 295.43 & 492.37 & 32.39 \\
\hline \multicolumn{9}{|l|}{ Fibers } \\
\hline Total diameter $(\mu \mathrm{m})$ & 14.57 & 21.53 & 38.45 & 16.74 & 15.38 & 21.57 & 34.41 & 16.18 \\
\hline
\end{tabular}




\begin{tabular}{ccccccccc}
\hline Wall Thickness $(\mu \mathrm{m})$ & 3.04 & 4.65 & 7.43 & 17.55 & 2.79 & 4.61 & 7.04 & 17.40 \\
Length $(\mu \mathrm{m})$ & 989.65 & 1353.07 & 1842 & 12.91 & 852.23 & 1353.39 & 2121.68 & 14.85 \\
\hline Radial parenchyma & & & & & & & & \\
Height $(\mu \mathrm{m})$ & 132.83 & 414.18 & 844.23 & 38.58 & 93.83 & 373.73 & 801.6 & 40.05 \\
Width $(\mu \mathrm{m})$ & 13.01 & 44.88 & 75.52 & 33.91 & 14.31 & 41.18 & 72.88 & 30.88 \\
\hline Apparent density $\left(\mathrm{kg} \cdot \mathrm{m}^{-3}\right)$ & 639 & 737 & 852 & 9.59 & 605 & 685 & 747 & 6.95 \\
\hline
\end{tabular}

\section{Chemistry: macro and micronutrients}

The analysis of macro (P, K, S, Mg and $\mathrm{Ca}$ ) and micronutrients ( $\mathrm{Se}, \mathrm{Cu}, \mathrm{Mn}, \mathrm{Ni}, \mathrm{Zn}$ and $\mathrm{Fe}$ ) showed a high percentage increments for copper and nickel, whose increases were of $100.83 \%$ and $70.93 \%$, respectively, between before and after first logging (Table 3 ).

Table 3. Average concentrations of macro and micronutrients in Copaifera langsdorffii wood before (19781987) and after (1988-1997) the first logging.

Tabela 3. Concentrações médias de macro e micronutrientes na madeira de Copaifera langsdorffii para os períodos pré (1978-1987) e pós (1988-1997) exploratórios.

\begin{tabular}{ccccccccccc}
\hline \multirow{2}{*}{ Period } & \multicolumn{10}{c}{ Nutrients $\left(\mathbf{m g . k g}^{-\mathbf{1}}\right)$} \\
\cline { 2 - 11 } & P & Se & Cu & Mn & Zn & Ni & Fe & Mg & Ca & K \\
\hline Pre 1987 & 105.04 & 74.72 & 2.11 & 236.96 & 14.05 & 3.08 & 90.11 & 724.38 & 1192.5 & 1359.2 \\
Post 1987 & 112.73 & 80.12 & 4.24 & 216.67 & 16.73 & 5.26 & 77.30 & 803.91 & 1281.1 & 1523.4 \\
\hline
\end{tabular}

\section{DISCUSSION}

The observed diametric increment pattern suggests higher rates of growth through environmental disturbances, such as the case of exploitation in the year of 1987 in response to the competitors' elimination and greater access to light. The opening of tree fall gaps, as a result of forest management, increases the transmittance of light, creating a more favorable environment for photosynthesis and the radial growth (PRÉVOST; RAYMOND, 2012). In tropical forests, the opening of tree fall gaps, either by the effect of management or by natural decrease, may influence the trees growth, causing intra and interspecific variations (SOUZA et al., 2014). The species can be characterized as elastic or inelastic in function of the ability to respond to changes in the environment (HIGUCHI; HIGUCHI, 2012). Therefore, it is possible that the trees of $C$. langsdorffii have presented elastic behavior, due to the diameter growth, or that the first forestry exploitation (1987) has been of sufficient intensity capable of promoting an increase in the tree growth rates.

The vessels frequency has a direct relation with the ascending flow of water and nutrients, being essential for plant physiology. The increase in the nutrients availability, due to the competitors elimination can directly affect the cells formation and induce changes in the vessels diameter and arrangement (SPANNL et al., 2016). Therefore, the hydraulic architecture of the arboreous species can be changed under adverse environmental conditions (COSME et al., 2017). In xeric environments, plants tend to gather the factors safety and water efficiency, increasing the frequency and reducing the vessels diameter. Changes in the conductor elements (arrangement, frequency, length, diameter, wall thickness and characteristics of the vessels pits) are fundamental adaptive responses that aim to ensure the increased resistance to cavitation, maintaining the security of hydraulic conductivity (AREF et al., 2013).

Although the present study cannot be characterized as xeric environment, the luminous intensity and the daily insolation are larger in treefall gaps and the incident light has different spectral quality than the one under the closed canopy (MUSCOLO et al., 2014). In the treefall gap, there is a greater amount of photosynthetically active radiation, which has vital importance in the plants development (MA et al., 2010). In these regions, the intensity of the radiation incident, per unit of time, is the primary variable capable of changing the microclimate, affecting, in its turn, soil characteristics, such as moisture, temperature and microbial activity (MUSCOLO et al., 2007a). Inside the treefall gaps, the water content in the soil is inversely proportional to the irradiance, due to the increase of evapotranspiration in these conditions (GAO et al., 2017). These factors can justify changes in the anatomy of $C$. langsdorffii, especially for the vessels frequency.

Among the micronutrients, copper acts in plant metabolism as an activator or component of enzymes that participate in organic reduction reactions (MARSCHNER, 1986). These enzymes act on electronic transport with change of valence (plastocyanin, laccase, ascorbic acid oxidase and cytochrome oxidase complex) and the electronic transport without change of valence (amine oxidase, tyrosinase and galactose oxidase). Plants deficient

FLORESTA, Curitiba, PR, v. 48, n. 3, p. 435-442, jul/set. 2018

Carmo. J. F. et.al.

ISSN eletrônico 1982-4688

DOI: $10.5380 /$ rf.v48i3. 57434 
in copper have reduced photosynthetic rate since more than $50 \%$ of copper located in chloroplasts are linked to plastocyanin, component of the electron transport chain of photosystem I. Hewitt and Smith (1975) reported that the optimal concentration of copper in the majority of plants is usually between 5 and $20 \mathrm{ppm} / \mathrm{dry}$ mass. The average value found in the regions corresponding to the period before to 1987 was below this minimum range (2.11 ppm), presenting an increase after the exploration date $(4.24 \mathrm{ppm})$. The effect of the treefall gaps may have influenced the absorption of this micronutrient, due to the increased availability of solar radiation and consequent increase of photosynthetic rates.

In plants, nickel is related to the hydrolysis of urea to ammonia $\left(\mathrm{NH}_{3}\right)$ and carbon dioxide $\left(\mathrm{CO}_{2}\right)$, catalyzed by the ureases, dependent enzymes of this micronutrient. In addition, it is related to other physiological processes, such as the nitrogen fixation (LOPEZ; MAGNITSKIY, 2011). Nickel acts as a fundamental component for the activity of several enzymes, such as: glyoxalases, deformilases peptide, methyl coenzyme M reductase, superoxide dismutase and hydrogenases (KURTMAN et al., 2013). The bioavailability of the component in the soil varies as a function of $\mathrm{pH}$, presence of organic matter, redox conditions, content of clays and hydrated oxides; and its carriage is performed from the roots to the aerial part via transpiratory flow (CHEN et al., 2009). The opening of treefall gaps provides high transmittance of photosynthetically active radiation, contributing to the increase of temperatures of the soil and air, as well as soil moisture reduction due to water evaporation (MUSCOLO et al., 2007b). The temperatures increase, proportional to the size of the treefall gaps, can generate significant increases in the plants evapotranspiration (GAO et al., 2017), generating a transpiratory flow ideal to nickel transport, when this is available in the soil.

\section{CONCLUSIONS}

- The increased availability of light and resources, arising from the opening of treefall gaps, promoted increase in diameter growth and the vessels frequency and, as a consequence, reduction of the wood density.

- It can be concluded that the species $C$. langsdorffii responds to stimuli caused by forest management, indicating possible adaptations of wood properties in response to silvicultural interventions.

- The understanding of wood changes, in function of the forest management activities, can subsidize the decisions taken regarding plantations, directing forestry operations in accordance with the market needs.

\section{REFERENCES}

AREF, I. M.; AHMED, A. I.; KHAN, P. R.; EL-ATTA, H. A.; IQBAL, M. Drought-induced adaptive changes in the seedling anatomy of Acacia ehrenbergiana and Acacia tortilis subsp. raddiana. Trees, Berlin, v. 27, n. 4, p. 959-971, 2013.

CASTELO, T. B. Legislação Florestal Brasileira e Políticas do Governo de Combate ao Desmatamento na Amazônia Legal. Ambiente \& Sociedade, São Paulo, v. 18, n. 4, p. 221-242, 2015.

CHEN, C.; HUANG, D.; LIU, J. Functions and toxicity of nickel in plants: recent advances and future prospects. Clean: Soil Air Water, Weinheim, v. 37, n. 4-5, p. 304-313, 2009.

COSME, L. H. M.; SCHIETTI, J.; COSTA, F. R. C.; OLIVEIRA, R. S. The importance of hydraulic architecture to the distribution patterns of trees in a central Amazonian forest. New Phytologist, Indianopolis, v. 215, n. 1, p. 113-125, 2017.

GAO, Z.; HE, J.; DONG, K.; LI, X. Trends in reference evapotranspiration and their causative factors in the West Liao River basin, China. Agricultural and Forest Mateorology, Amsterdam, v. 232, p. 106-117, 2017.

HEWITT, E. J.; SMITH, T. A. Plant Mineral Nutrition. London: English University Press, 1975.

HICKEY, G. M. Evaluating sustainable forest management. Ecological Indicators, Amsterdam, v. 8, n. 2, p. 109-114, 2008.

HIGUCHI, M. I. G.; HIGUCHI, N. A Floresta Amazônica e suas múltiplas dimensões: uma proposta de educação ambiental. 2. ed. Manaus: Embrapa Florestas, 2012.

IAWA, C. IAWA list of microscopic features for hardwood identification. IAWA Journal, Leiden, v. 101, n. 10, p. 219-232, 1989.

JOHANSEN, D. A. Plant microtechnique. New York: McGraw-Hill Book, 1940.

KURTMAN, B. Y.; KURTMAN, U. B.; CAKMAK, I. Nickel- enriched seed and externally supplied nickel 
improve growth and alleviate foliar urea damage in soybean. Plant and Soil, Berlin, v. 363, n. 1-2, p. 61-75, 2013.

KUSUMOTO, B.; SHIONO, T.; MIYOSHI, M.; MAESHIRO, R.; FUJII, S.; KUULUVAINEN, T.; KUBOTA, Y. Functional response of plant communities to clearcutting: management impacts differ between forest vegetation zones. Journal of Applied Ecology, Indianopolis, v. 52, n. 1, p. 171-180, 2015.

LONGHI, R. V.; SCHNEIDER, P. R.; LONGHI, S. J.; MARANGON, G. P.; COSTA, E. A. Growth dynamics of araucaria after management interventions in natural forest. Floresta e Ambiente, Seropédica, v. 25, n. 2, p. 110, 2018.

LOPEZ, M. A.; MAGNITSKIY, S. Nickel: The last of the essential micronutrients. Agronomía Colombiana, Bogotá, v. 29, n. 1, p. 49-56, 2011.

MA, S.; CONCILIO, A.; OAKLEY, B.; NORTH, M.; CHEN, J. Spatial variability in microclimate in a mixedconifer forest before and after thinning and burning treatments. Forest Ecology and Management, Amsterdam, v. 259, n. 5, p. 904-915, 2010.

MARSCHNER, H. Mineral Nutrition of Higher Plants. London: Academic Press Inc., 1986.

MEDEIROS, R. da S.; VIEIRA, G.; ALMEIDA, D. R. A. de; TOMAZELLO FILHO, M. New information for managing Copaifera multijuga Hayne for oleoresin yield. Forest Ecology and Management, Amsterdam, v. 414, p. 85-98, 2018.

MUSCOLO, A.; BAGNATO, S.; SIDARI, M.; MERCURIO, R. A review of the roles of forest canopy gaps. Journal of Forest Research, Berlin, v. 25, n. 4, p. 725-736, 2014.

MUSCOLO, A.; SIDARI, M.; MERCURIO, R. Influence of gap size on organic matter decomposition microbial biomass and nutrient cycle in Calabrian pine (Pinus laricio, Poiret) stands. Forest Ecology and Management, Amsterdam, v. 242, n. 2-3, p. 412-418, 2007a.

MUSCOLO, A.; SIDARI, M.; MERCURIO, R. Variations in soil chemical properties and microbial biomass in artificial gaps in silver fir stands. European Journal of Forest Research, Berlin, v. 126, n. 1, p. 59-65, 2007b.

PARK, J.; KIM, T.; MOON, M.; CHO, S.; RYU, D.; SEOK KIM, H. Effects of thinning intensities on tree water use, growth, and resultant water use efficiency of 50-year-old Pinus koraiensis forest over four years. Forest Ecology and Management, Amsterdam, v. 408, p. 121-128, 2018.

PRÉVOST, M.; RAYMOND, P. Effect of gap size , aspect and slope on available light and soil temperature after patch-selection cutting in yellow birch - conifer stands, Quebec , Canada. Forest Ecology and Management, Amsterdam, v. 274, p. 210-221, 2012.

SOUZA, D. V.; CARVALHO, J. O. P.; MENDES, F. S.; MELO, L. O.; SILVA, J. N. M.; JARDIM, F. C. S. Growth of Manilkara huberi and Manilkara parensis after logging and silvicultural treatments in the municipality of Paragominas, Para, Brazil. Floresta, Curitiba, v. 44, n. 3, p. 485-496, 2014.

SPANNL, S.; HOMEIER, J.; BRÄUNING, A. Nutrient-Induced Modifications of Wood Anatomical Traits of Alchornea lojaensis (Euphorbiaceae). Frontiers in Earth Science, Lausanne, v. 4, n. 2, p. 1-13, 2016.

FLORESTA, Curitiba, PR, v. 48, n. 3, p. 435-442, jul/set. 2018

Carmo. J. F. et.al.

ISSN eletrônico 1982-4688

DOI: 10.5380/rf.v48i3. 57434 
FLORESTA, Curitiba, PR, v. 48, n. 3, p. 435-442, jul/set.2018

Carmo. J. F. et.al. 